Cahiers $d u$ MONDE RUSSE

\section{Cahiers du monde russe}

Russie - Empire russe - Union soviétique et États indépendants

$62 / 4 \mid 2021$

Varia

Gregory AFINOGENOV, Spies and Scholars. Chinese Secrets and Imperial Russia's Quest for World Power

\title{
Fengfeng Zhang
}

\section{OpenEdition}

\section{Journals}

Electronic version

URL: https://journals.openedition.org/monderusse/12795

DOI: 10.4000/monderusse. 12795

ISSN: $1777-5388$

\section{Publisher}

Éditions de l'EHESS

\section{Printed version}

Date of publication: 1 December 2021

Number of pages: 703-705

ISBN: 978-2-7132-2895-7

ISSN: $1252-6576$

\section{Electronic reference}

Fengfeng Zhang, "Gregory AFINOGENOV, Spies and Scholars. Chinese Secrets and Imperial Russia's Quest for World Power", Cahiers du monde russe [Online], 62/4 | 2021, Online since 01 December 2021 connection on 03 September 2022. URL: http://journals.openedition.org/monderusse/12795 ; DOI https://doi.org/10.4000/monderusse. 12795

This text was automatically generated on 3 September 2022.

All rights reserved 


\title{
Gregory AFINOGENOV, Spies and Scholars. Chinese Secrets and Imperial Russia's Quest for World Power
}

\author{
Fengfeng Zhang
}

\section{REFERENCES}

Gregory AFINOGENOV, Spies and Scholars. Chinese Secrets and Imperial Russia's Quest for World Power, Cambridge, MA - London : The Belknap Press of Harvard University Press, 2020, 367 p.

1 As two great neighboring powers, Russia and China experienced a long history of bilateral relationships from the 17th to the 19th centuries. However, related academic research is rather scarce and lacks systematic studies on the way in which Imperial Russia approached China through intelligence gathering. Gregory Afinogenov's pioneering, elaborate study sheds new light on the topic by delving into the history of Russia's knowledge of China. The knowledge regime notion put forward by social scientists John L. Campbell and Ove Kaj Pedersen constitutes the dominant theoretical framework of the book, and Afinogenov's historical account draws on scores of archives and other primary sources from Russia and other European countries.

2 In Campbell and Pedersen's definition, "knowledge regimes are the organizational and institutional machinery that generates data, research, policy recommendations, and other ideas that influence public debate and policymaking." This definition underpins Afinogenov's argument that Russian institutions were related to one another and to state policy. In other words, intelligence institutions, intellectuals and individuals were all tied to Imperial Russia's building of its knowledge regime. Afinogenov's study is not just a monograph tracing the development of Russia's sinology, nor is it simply about how Russia expanded southeastwards. Rather, it is a systematic study of the various stages of Imperial Russia's knowledge regime on China during the two centuries. 
3 During the building process of Muscovite statecraft, Muscovy gradually constructed frontier knowledge through hybrid texts. It was only after the reforms of Peter the Great that Russia gradually got more direct intelligence on China (two noteworthy precedents in the 17th century must be noted, however: Petlin's visit to the Ming government in 1618 and Baikov's embassy in Beijing in 1652). Formerly, Russia tried to understand the Qing Dynasty through hybrid documents incorporating various European, Jesuit, Russian and Inner Asian sources. In the pre-Petrine era, Muscovy avidly gathered intelligence on China; Europeans even got intelligence about China by stealing, adapting and publicizing privileged Muscovite geographical knowledge. The Petrine era effected changes in institutions of intelligence gathering: the Imperial Academy of Sciences was in charge of producing public knowledge and the College of Foreign Affairs dealt with secret knowledge.

During the post-Petrine era, the state tried to train a group of experts on China via the Russian Ecclesiastical Mission in Beijing and got to form only a small class of specialists. Afinogenov recounts the fates of students of the mission such as Rossokhin, Kaniaev, Leont'ev, Vladykin and others. Most of these specialists and their successors failed to be influential public intellectuals after their return to Russia because of lack of institutional support and constraints on publications in the elite-centered intellectual culture. They mostly acted as translators and teachers of Manchu and Chinese and finally sunk into obscurity. Thus, though members of the Imperial Academy of Sciences tried to make claims on a broader scholarly world, their status as technicians of the imperial knowledge regime was an obstacle to their being scholars with intellectual prestige in Western Europe. Another institutional change in intelligence gathering about China was the state-run trade caravan between Moscow and Beijing: caravan directors, clerks, doctors and merchants sought geographical information and were engaged in industrial espionage aimed at stealing specific technical recipes from the Qing, be it for porcelain production and alcohol distillation, and in metallurgy. Alongside its commercial role, the caravan also functioned as a carrier of correspondence between the Academy in St. Petersburg and the Jesuit mission in Beijing. In addition, merchants and officials in Russia's frontier areas also transmitted knowledge to Russia through letters.

When the Qing quelled the Junghar Confederation in the 1750s, intelligence became a tool of choice for Russia, and both military officers and traders circulated intelligence widely and secretly as Russia claimed the region on the former Russo-Junghar frontier. Kazakh, Uriangkhai, Torghut, etc., issues were also at stake. Besides, frontier intelligence played a role in Russia's struggle for Inner Asia when it dealt with frontier affairs. In Eastern Siberia, governed by Russian officials like Iakobii, Kropotov and their successors, an intelligence network was established to subvert Khalkha (Outer) Mongolia, but the consequences were not as significant as the investments because of the region's peripheral position and Russia's weak military power there.

6 From the end of the 18th century, Russian, British, French and other powers' intelligence apparatuses competed for influence over the geopolitics of the new North Pacific arena. Thus, in the age of Napoleon, Russia devised new strategies for expansion and strove to develop its own sinology to prepare the ground for future encroachments on southeastern territories. Besides Britain, other powers like France, Holland and North America spurred Russia to expand on the Amur River. Sinology also played a role at the time. It was a competition tool against European countries, which had transformed frontier intelligence-gathering into Western Orientalism. Reforms were needed and 
Archimandrite Pëtr Kamenskii turned Russian sinology into a professionalized discipline. In the 1850s, the new generation of administrators on the Mongolian frontier, notably Nikolai Murav'ev, manipulated anxieties about foreign rivals and finally materialized the conquering aspirations of their predecessors through an intelligence coup. The knowledge regime served as an adjunct power for the state, contributing to Russia's annexation of the territory north and east of Amur River.

7 In general, this book deconstructs the building of Imperial Russia's knowledge on China from multiple angles, concluding that Russia's intelligence gathering and the history of its knowledge about China were closely related to Russia's growth as an expanding power. Thus, Afinogenov interprets the history of Imperial Russia from a special perspective, and gives relevance to both bureaucratic institutions and frontier issues. On the whole, this theme has rarely been unraveled before as it is related to the history of secret intelligence gathering and the establishment of Imperial Russia's interior knowledge system. Without referring to a cornucopia of archives, manuscripts, correspondence and other primary sources, it would have had difficulty penetrating the academic lacuna in the Russo-Qing relationship, which is undoubtedly a cutting-edge field of New History. Moreover, it is also connected with the popular global or transnational history because it simultaneously incorporates the histories of Russia, China, and other European powers. Unlike other traditional studies, it focuses on the frontier history between the two countries and thus pays attention to cross-border ties and the intermediate roles played by missionaries, translators, traders and other individuals in building an intelligence network. He also notes the issues at stake in east Siberia and Inner Asia, including Xinjiang and Mongolia. He mentions the histories of the Junghar, Torghut, and Kazakh, which may be too peripheral to be mentioned in other studies. So, this solid monograph is sophisticated and merits attention, praise, and appreciation.

8 Afinogenov mainly uses archives and manuscripts from Moscow, St. Petersburg, London, and Paris, and shies away from sources in Chinese. This is not fully convincing as his study is related to Chinese history, and he neglects the key archives stored in Beijing he does, however, cite a few studies by Chinese scholars like Yan Guodong and Ye Baichuan. Certainly, his account is from the point of view of Russia, but it could be improved if complemented with more Chinese primary sources including archives and other historical records. Some archives on Sino-Russian relations have long been compiled and published in China, and comparisons between the records in Russian and Chinese can be meaningful. Moreover, Afinogenov fails to mention one of the most relevant and detailed books by Yan Guodong, A History of Russia's Sinology, published in 2006, in which Yan comprehensively describes the development of Russia's sinology from the 17th century to 1917 and studies the lives of famous sinologists such as Rossokhin, Leont'ev, Agafonov, Vladykin or Lipovtov. Yan also classifies Russian sinologists into different schools in the latter half of the 19th century and describes their contribution to Manchu, Mongolian, Tibetan studies and other subjects. Additionally, Afinogenov may need to pay more attention to the Qing state's reactions to Russian issues. More comparisons can be made between Russia's annexation of the Amur River region and central Asian areas in the light of the competition between different Western powers. It also would have been worthwhile to highlight the tumultuousness that marked Qing history from the 1840s in the last part of the account. 


\section{AUTHORS}

FENGFENG ZHANG

School of History and Culture

South China Normal University 